\title{
The effect of urban green roof design on beetle biodiversity
}

Sydney Gonsalves ( $\square$ sydney.gonsalves@gmail.com )

Anchor QEA LLC https://orcid.org/0000-0003-2603-3882

Olyssa Starry

Portland State University

Alexander Szallies

Zurich University of Applied Sciences: Zurcher Hochschule fur Angewandte Wissenschaften

Stephan Brenneisen

Zurich University of Applied Sciences: Zurcher Hochschule fur Angewandte Wissenschaften

\section{Manuscript}

Keywords: urban biodiversity, habitat complexity, green roof, beetle, Hill numbers

Posted Date: February 12th, 2021

DOl: https://doi.org/10.21203/rs.3.rs-164289/v1

License: (a) (1) This work is licensed under a Creative Commons Attribution 4.0 International License. Read Full License

Version of Record: A version of this preprint was published at Urban Ecosystems on July 21st, 2021. See the published version at https://doi.org/10.1007/s11252-021-01145-z. 


\section{Abstract}

The value of urban green spaces to biodiversity conservation depends on the design and management. The importance of habitat quality and complexity to species diversity has led to the suggestion that habitat design elements-varied substrate depth, greater plant diversity, logs or stones-would support invertebrate diversity on green roofs. To evaluate this possibility, we conducted pit-fall trap sampling on three green roofs of simple design (intended primarily for stormwater management), three habitat roofs, and five ground-level green spaces, in the Portland, Oregon metropolitan area. Beetles (Coleoptera) were sampled as representatives of total invertebrate diversity. Diversity was compared using sample coverage and Hill numbers to account for differences in sample intensity and fundamental differences in species diversity. Both habitat roofs and ground sites consisted of just over $20 \%$ native species, while stormwater roofs had about $5 \%$ native species, all of which were considered pests. We collected a greater abundance of beetles on the ground compared to roof sites like others have shown. However, when sample completeness is taken into account, habitat roofs had greater Shannon diversity compared to both ground and stormwater roof sites. Habitat roofs had the fewest dominant species representing $5 \%$ or more of total abundance, but also the lowest percent of species represented by singletons (27\%). These results indicate that green roofs can support different beetle communities compared to those present at ground-level urban green spaces; our results also support previous findings that biodiverse design can reliably increase green roof diversity compared to more simply designed roofs.

\section{Introduction}

Urban areas represent one of earth's few ecosystems that are increasing in extent while other types of habitat continue to be lost through degradation, fragmentation, and land-use conversion (Pickett et al. 2011; Pataki 2015; UN 2016). Globally, this has resulted in species loss on every scale from large mammals to insects to microbes (Burkepile and Thurber 2019; Klink et al. 2020). Urban areas are often perceived as disturbed areas of little ecological value, but in fact are a unique type of ecosystem that can support important pools of biodiversity, including rare and endangered native species (Pickett et al. 2008; Kowarik 2011; Grimm et al. 2017). The value of urban green spaces to biodiversity conservation often depends on the design and management of such spaces (Aronson et al. 2017).

Small ground-level urban green spaces like gardens, lawns, parks, brownfields, and historic land cover remnants have been shown to be important refuges for native species (Croci et al. 2008; Lorimer 2008; Pickett et al. 2008; Goddard et al. 2011). The ability of ground-level green spaces to provide habitat has fueled speculation by researchers and municipalities that green roofs may also help conserve and restore biodiversity in urban areas (Landolt 2001; Brenneisen 2003; Brenneisen 2006a; Gedge and Kadas 2006; Cook-Patton and Bauerle 2012; Williams et al. 2014). A comparative study of spider communities of nearnatural managed railroad areas with species-rich ruderal vegetation and structure-rich green roofs with different vegetation showed comparable species numbers in both habitat types (Brenneisen 2006b). Independent of the differences between roof and ground locations, it could be shown, however, that green roofs can also be permanently populated by stenoecious and Red Data Book listed species, which proves their possible suitability in principle as compensation habitats for urban biodiversity promotion and conservation aspects (Brenneisen 2003; Pétremand et al. 2017; Pétremand et al. 2018) However, in comparisons of green roofs to nearby ground-level urban green spaces, other studies found invertebrate species richness and abundance tended to be greater on the ground (Maclvor and Lundholm 2011; Tonietto et al. 2011; Ksaizek et al. 2012).

As habitat, green roofs can suffer markedly from the characteristics of habitat fragmentation: (1) isolation, (2) small area, and (3) poor habitat quality. These characteristics are known to be negatively related to species biodiversity (McArthur and Wilson 1967; Tscharntke et al. 2002). For example, green roofs on higher buildings were less likely to be nested on by bees and wasps (Maclvor 2015). A review of urban invertebrates found that the species-area relationship generally held for a variety of green spaces and locales (Jones and Leather 2012), though at least one study has found that green roof area did not strongly influence arthropod community (Braakar et al. 2014).

Of the three aforementioned characteristics of habitat fragmentation, green roof design has the most potential to improve habitat quality, which could help mitigate the negative effects of isolation and small area on species diversity (Rosenzweig 1995; Tscharntke et al. 2002). The potential benefits of greater habitat quality have led green roof organizations and local governments to publish guidelines for "biodiverse" or "habitat" roof designs in hopes of provisioning rare, native, and specialist species (Nikles et al. 2020; City of Toronto 2020). In this paper we refer to green roofs that incorporate design elements aimed at improving habitat quality as "habitat roofs". These elements could include planting native vegetation of multiple functional groups, the use of native soil as substrate, variation in substrate thickness, and the addition of elements such as logs and stones (Brenneisen 2003, 2006a; Gedge and Kadas 2005). In contrast, we define "stormwater roofs" as those whose primary function is to retain or detain stormwater; these are often thinner roofs planted with a variety of succulent species. Understanding how habitat quality can increase green roof species diversity is important to maintaining and creating critical patches of biodiversity in the face of increasing urbanization (Williams et al. 2014, Pickett et al. 2008; Sattler et al. 2011).

Improved habitat quality can combat the effects of small fragment size if it results in increased habitat complexity (Tscharntke et al. 2002; Kovalenko et al. 2012). Greater habitat complexity is thought to increase species diversity because it provides more micro-habitats and therefore more niches for species to occupy (MacArthur and MacArthur 1961; Tews et al. 2004; Kovalenko et al. 2012). In terrestrial systems, habitat complexity is often defined by plant community (Tews et al. 2004; McAbendroth et al. 2006; Srivastava 2006), but it may also be defined by topography, substrate variation, or the presence of animal species that alter or provide physical structure (Kovalenko et al. 2012). Habitat complexity can also be provided by man-made structures that provide shade, overhanging features, or attachment points for organisms (Ido and Shimrit 2015). On green roofs, these structures include air conditioning units, solar panels, and railings.

Some studies have previously evaluated the effect of green roof habitat complexity on invertebrate diversity. A study in Switzerland found that while green roofs designed with elements like vegetation of multiple height layers, woody debris, and topographic variation had greater colonization rates of beetles and spiders, the number of rare and endangered species was similar across roof types (Brenneisen 2006a). In London, habitat roofs have been designed to mimic 
derelict industrial land, since ground-level brownfields are known to be hotspots of invertebrate biodiversity in England (Gedge and Kadas 2005; Kadas 2006; Bates et al. 2009, 2013). When compared with Sedum genus mat planted roofs, so called "brown roofs" (term related to the brownfield) had lower invertebrate species richness and diversity; however, the result was confounded by the younger age of the brown roofs (Kadas 2006). Most studies of green roofs include only a small number of sites. However, one unique study used a quick survey method (10 minute per roof) to sample 115 green roofs across a wide swath of northern France (Madre et al. 2013). While this study did not aim to fully document roof arthropod richness, it allowed for important intra-roof comparison showing that roofs with more vegetation layers (i.e., more complexity) had greater total arthropod abundance and richness (Madre et al. 2013).

In addition to abundance and richness, measures of relative abundance, community similarity, functional groups, and the presence of specialized or native species are important for describing overall biodiversity. On roofs, local characteristics like percent herbaceous cover, number of flowering plants, or amount of bare ground may help explain community composition of arthropod groups (Braakar et al. 2014). At ground-level, urban arthropod community similarity may be more strongly associated with land-use and vegetation type than physical distance between communities (Mclntyre et al. 2001; Angold et al. 2006). A study in Basel (Switzerland) showed that local and landscape variables are playing a role in structuring beetle communities on green roofs, while at the individual species level, local roof variables were more important than characteristics of the surrounding urban landscape (Kyrö et al. 2017).

However, for invertebrate groups with greater mobility, physical proximity between roof and ground-level green spaces may be more important for community similarity (Braakar et al. 2014). Isolated and disturbed sites are associated with smaller body size species (Ksiazek et al. 2012; Jones and Leather 2012) and, while native species are found on green roofs, there may be fewer than at nearby ground-level green spaces (Tonietto et. al. 2011).

In this study, we examine beetle (Coleoptera) communities on green roofs of two different designs (habitat roofs and stormwater roofs) and nearby groundlevel urban green spaces in Portland, Oregon. We use this evaluation to answer the following questions: (1) Do habitat roofs, which were designed with habitat quality and complexity in mind, have greater beetle species diversity than stormwater roofs and green spaces on the ground? (2) Are differences in species diversity between habitat roofs, stormwater roofs, and the ground reflected in beetle community composition, presence of native or rare species, or proportions of body sizes represented?

\section{Methods Site Description}

The sampled roof sites were chosen based on access availability and description in the City of Portland Ecoroof Database (Starry 2020). Ground sites were chosen based on accessibility and proximity to green roofs. Descriptive characteristics of the sites are summarized in Table 1. Three stormwater roofs were located in downtown Portland and were retrofits on existing buildings (Fig 1). These three stormwater roofs had an average substrate depth of $7.5 \mathrm{~cm} \pm$ $1.7 \mathrm{~cm}$ (Mean \pm SD) and an average substrate organic content of $8.7 \% \pm 1.0 \%$. Two of the SW roofs were planted with low-growing, drought resistant plant species of the Sedum genus only. The third roof was planted predominantly with Sedums but had two small areas ( $<10 \%$ of total vegetated area) of herbaceous ornamental plants near the access points. The stormwater roofs were 3 to 5 years in age with vegetated areas ranging from $227-873 \mathrm{~m}^{2}$. All three stormwater roofs had railings and partial overhangs from higher parts of the building and two had solar panels.

Two habitat roofs were located downtown and were retrofits while the third habitat roof was located just north of downtown in an industrial area. The habitat roofs had an average substrate thickness of $10.1 \mathrm{~cm} \pm 1.8 \mathrm{~cm}$. Additionally, all three had purposely varied substrate depth to create spatial heterogeneity. The habitat roofs had an average substrate organic content of $12.4 \% \pm 6.6 \%$ and were planted with a mix of herbaceous, shrubby, and drought tolerant native and non-native species. Two of the habitat roofs also had woody debris to further increase habitat complexity. The habitat roofs were 4 to 16 years in age with vegetated areas ranging from $194-1,858 \mathrm{~m}^{2}$. All of the habitat roofs had railings, two of the roofs had air conditioner units, and one roof had sky-lights.

Ground locations were selected based on accessibility within 200 meters of a roof location. In downtown Portland, two ground locations were undeveloped grassy lots; one was a landscaped area with a mixture of horticultural species, one was a neglected industrial area dominated by weedy colonizers, and one was in a public park with a grassy area and an area planted with native Pacific Northwest species. Ground location details are shown with their nearest roof site in Table 1.

\section{Beetle Sampling}

Beetles were sampled using ten pitfall traps at each site filled with $10 \%$ acetic acid. They were emptied and refilled biweekly. The traps consisted of $125 \mathrm{ml}$ plastic cups with approximately $5 \mathrm{~cm}$ diameter opening, along with a $5 \mathrm{~cm}$ diameter PVC holder sleeve installed in the ground. A plastic cover prevented the traps from being flooded with rainwater. A study of pitfall trapping (Ward et al. 2001) found that traps spaced less than $5 \mathrm{~m}$ apart interfered with each other and reduced the number of beetle morphospecies caught. However, there was no difference in number of beetle morphospecies between traps spaced 5 to 10 meters apart. Therefore, we maintained a 5-10m inter-trap spacing, placing the ten traps in a $5 \times 2$ grid format. In cases where this placement was not possible due to the shape of vegetated area, the traps were placed at a diagonal to each other while maintaining inter-trap spacing. The use of pitfall traps has well known limitations that bias catches towards high activity, surface and soil dwelling organisms, and under-sample beetles that live in higher vegetation levels (Woodcock 2005). However, pitfall traps can be used to sample continuously and cause low levels of disturbance while sampling (Woodcock 2005).

In order to minimize trap disturbance, a wire exclosure was placed around the traps toward the end of the season. The influence of exclosures on trap catch was tested at one roof with low disturbance by deploying exclosures on half the traps for two weeks. No difference in total catch number or rough taxonomic distribution was noted. The exclosures were secured by garden staples or, if roof substrate was not deep enough, a brick was placed on top of the cage.

Page $3 / 16$ 
Because traps were sometimes still disturbed by crows and humans, creating an uneven sampling intensity across sites, samples were compared by completeness as described in more detail in the data analysis section (Chao et al. 2014).

Predominant invertebrate groups collected in the pitfall traps included earth worms (Class: Clitellata), spiders (Order: Araneae), mites (Order: Acari), springtails (Subclass: Collembola), and insects (Class: Insecta). Beetles were selected since they are shown to be good indicators total invertebrate diversity in multiple habitat types (Duelli and Obrist, 1998; Cameron and Leather 2012).

For this analysis, only beetles (Order: Coleoptera) were retained for identification to species level and stored in a $70 \%$ ethanol, $20 \%$ acetic acid mixture. In 13 cases, a species-level identification was not made for a sample and it was identified only to genus level. Beetles species were assigned to the following feeding groups for soil and low vegetation food webs in the Pacific Northwest: generalist predator, parasitoid, omnivore, generalist herbivore, specialist herbivore (i.e.granivore, root chewer, moss feeder, fungivore), and detritivore (Moldenke 1999). Feeding group assignments were based on best professional advice (Andrew Moldenke, personal communication 2014) and a species-specific literature review. If a species-level identification was not made for a sample, it was assigned to a feeding group based on genus-specific information. Each species was also assigned an invasiveness and a body size classification based on a species-specific literature review (see Supplemental Information). Invasiveness classifications were native, native pest, non-native, invasive, or unknown if the species level identification was not made. A species was classified as invasive if it was non-native and one or more references documented an expanding range, economic damage, detrimental effects on native species, or used the word "invasive" or "pest". Body size classifications were $<5 \mathrm{~mm}$, "Small”; 5-10mm, “Medium", <10mm, "Large" (Fattorini et al. 2013).

\section{Data Analyses}

All data analyses were performed using R Statistical software (R Core Team 2018); see below regarding specific packages.

\section{Estimation of Species Diversity}

A challenge in determining how green roof design and habitat complexity contribute to invertebrate diversity is the wide range of biodiversity metrics available (Chao et al. 2014). Recently, an Ecological Society of America forum advised moving towards a "species equivalent" estimate of diversity (Ellison 2010; Jost et al. 2010). This means that estimated diversity is equivalent to that of a theoretical assemblage with $n$ equally abundant species (Chao et al. 2014). One approach is to use Hill numbers- a family of diversity indices that are species equivalents of well-known diversity metrics: richness, Shannon entropy, and Simpson index (Hill 1973). Interpolation and extrapolation of Hill numbers allow samples of different sizes to be more easily be compared (Chao et al. 2014).

Because habitat roofs, stormwater roofs, and ground sites may have fundamental differences in beetle abundance and diversity and experience different levels of disturbance during sampling, sample completeness (rather than sample size) was used as an unbiased measure for comparing samples. The method for determining reference sample completeness is adapted from numbers theory and is based on the observed frequency of singletons ( $f_{1}$ ), doubletons $\left(f_{2}\right)$, and the total number of individuals sampled (Chao and Jost 2012). Chao and Jost (2012) suggest that reference sample completeness should be at least $50 \%$.

Rather than rarefy samples to the smallest sample completeness, sample interpolation and extrapolation was performed to allow for a range of comparison. Extrapolation was extended comparison up to two times the smallest numbers of equivalent sample sizes (Colwell et al. 2012; Chao et al. 2014). The first three Hill numbers $(q=0,1,2)$, which represent species richness, Shannon diversity, and Simpson diversity were used as diversity metrics and bootstrapped $95 \%$ confidence intervals were constructed over the range that metrics were estimated. Analysis was implemented using the iNEXT package in $\mathrm{R}$ (Hsieh et al. 2020).

\section{Body Size Comparison}

After sampled individuals were assigned to body size classifications, a Chi-Squared test was used to determine if the proportion of individuals of different sizes varied by site type. A false discovery rate method was used to correct for multiple comparisons during post-hoc testing (Benjamini and Hochberg 1995).

\section{Indicator Species}

An analysis to determine strongly associated species was performed using the indicspecies R package (De Cáceres and Legendre 2009). Indicator species may not be the most abundant species since the algorithm measures the association of a species to site type based on the product of specificity and sensitivity. Specificity is the likelihood a site belongs to the target site group given the fact that the species has been found, while sensitivity is the likelihood that the species will be found at one site type only (De Cáceres 2020). A maximum indicator value statistic of 1 would be calculate for a species that is found at all sites of a particular group and is only found at sites of that group. A p-value is then calculated to the association between species and site group using a bootstrap method ( $\mathrm{n}=10000, \mathrm{a}=0.1$; De Cáceres 2020).

\section{Community Similarity}

Similarity of beetle community at each sampled location was evaluated using the Bray-Curtis (BC) dissimilarity index in the vegan package in R (Oksansen et al. 2019). A similarity tree was developed based on Ward's minimum variance hierarchical clustering method. The Ward method defines groups in such a way 
that the within-group sum of squares is minimized (Borcard et al. 2013).

\section{Results}

A total of 90 beetle species and 3,930 individuals were found within the Portland urban area. Fifty species were found only at ground sites and 11 were found only at green roof sites. Of species found only on green roofs, 9 were found only on habitat roofs, while two were found only on stormwater roofs. The most common beetle family at ground sites and stormwater roofs was Staphylinidae followed by Carabidae. On habitat roofs the pattern was reversed with Carabids being more common than Staphylinids.

Overall, both habitat roofs and ground sites consisted of just over $20 \%$ species native to North America, while stormwater roofs had about $5 \%$ native species, all of which were considered pests. One invasive species (Nebria brevicollis) was identified and was found at all ground sites, one habitat roof, and one stormwater roof.

Over half of all species found on habitat roofs (55.3\%), $71.5 \%$ of ground site species, and $82.6 \%$ of stormwater roof species were classified as generalist predators. Only a small percent, $0.25 \%$ on habitat roofs and $0.06 \%$ at ground sites, were classified as parasitoids or specialist predators (mite eater). On habitat roofs, $36.7 \%$ of species were classified as facultative generalist herbivores or as omnivores. For stormwater roofs, $14.5 \%$ of species and at ground sites $14.0 \%$ of species were identified as such. Ground sites had the most species (13.0\%) classified as specialist herbivore (granivore, moss eater, root eater, fungivore). Habitat roofs had the next most specialist herbivores (6.7\%) followed by stormwater roofs (2.9\%). Detritivore were the least represented feeding group, making up $1.4 \%$ of ground site species, $1 \%$ of habitat roof species, while none were found on stormwater roofs.

\section{Species Diversity}

Habitat roofs had 36 species among 403 individuals; the number of singletons was $f_{1}=10$ and the number of doubletons was $f_{2}=2$ (Fig $\left.2 a\right)$. The coverage estimate for the reference sample was $97.5 \%(S E=1.4 \%)$. Stormwater roofs had 16 species among 69 individuals; the number of singletons was $f_{1}=7$ and the number of doubletons was $f_{2}=3$, yielding a sample coverage of $90.0 \%$ (SE $=6.7 \%$ ). At the ground sites, we found 79 species among 3,458 individuals; the number of singletons was $f_{1}=25$ and the number of doubletons was $f_{2}=8$, yielding a sample coverage of $99.2 \%$ (SE $=0.25 \%$ ). The top five most abundant species for each site type are shown in Table 2.

Doubling the number of individuals found is the maximum recommended for extrapolation (Chao and Jost 2012; Cowell et al. 2012). This allowed the lowest abundance stormwater roofs to be extrapolated to 138 individuals and for comparison of diversity up to $98 \%$ sample completeness (Fig $2 \mathrm{~b}, \mathrm{c}$, and d).

For a Hill number of $q=0$ (species richness), habitat roofs were estimated to be the most diverse for sample sizes up to approximately $88 \%$ sample coverage. When sample coverage was greater than $88 \%$, ground sites had the greatest richness (Fig $2 \mathrm{~b}$ ). Non-overlapping $95 \%$ confidence intervals indicate that the differences were significant (Chao and Jost, 2012). At all sample coverages, stormwater roofs had the lowest species richness. stormwater roofs had similar richness to ground sites until approximately $75 \%$ sample coverage. Above $75 \%$ coverage stormwater roofs had the lowest species richness, although confidence intervals for habitat roof and stormwater roof richness overlapped at coverages greater than $93 \%$.

Habitat roofs had significantly greater Shannon diversity (Hill number q = 1) at all sample coverages (Fig 2c). Ground sites had greater Shannon diversity than stormwater roofs, but the difference was not statistically significant since the $95 \%$ confidence intervals were fully overlapping at all sample coverages.

Habitat roofs had significantly greater Simpson diversity (Hill number q = 2) than stormwater roofs up to a sample coverage of approximately $65 \%$ and greater than ground sites up to a sample coverage of approximately $80 \%$ (Fig $2 \mathrm{~d}$ ). Above $65 \%$ sample coverage there is a large amount of overlap in the confidence intervals for Simpson diversity between habitat and stormwater roofs. Above $80 \%$ sample coverage, there is slight overlap in the $95 \%$ confidence intervals for Simpson diversity between habitat roofs and ground sites.

Habitat roofs had the fewest dominant species representing $5 \%$ or more of total abundance ( 3 species), but also the lowest percent of species represented by singletons (27\%) and doubletons (5.5\%). On the ground, six dominant species that represented $5 \%$ or more of individuals made up $75 \%$ of total abundance, while a larger number of species were represented as singletons (31\%) and doubletons (10\%) than habitat roofs. This is reflected in the greater richness on the ground as sample coverage approaches $100 \%$. Stormwater roofs had the highest percent of species represented as singletons (43\%) and doubletons (19\%) but also had 5 dominant species that relatively evenly $(9 \%-28 \%)$ represented $77 \%$ of total abundance. This was reflected in the similar estimates of Simpsons diversity at all sample completeness levels for stormwater roofs compared to the ground (Fig 2d).

\section{Body Size Comparison}

We found that ground sites were composed primarily of large (53.4\%) and medium-bodied species (36.2\%), and relatively few small-bodied species (9.5\%). Habitat roofs had the most medium (65.3\%) and small-bodied species (23.1\%) and the fewest large-bodied species (11.7\%). stormwater roofs had the most small-bodied species (36.2\%), as well as the most even distribution of body sizes with $34.8 \%$ medium and $29.0 \%$ large-bodied species. Chi-squared testing showed that relative percentages of small, medium, and large bodied species were significantly different between site types $\left(\chi^{2}=57.6, \mathrm{df}=4, \mathrm{p}\right.$-value $=9.3 \mathrm{e}-$ 12). Post-hoc testing indicated that habitat roofs had a significantly different distribution of body sizes compared to stormwater roofs and ground sites (habitat-stormwater: $\mathrm{p}$-adj $=1.30 \mathrm{e}-05$, habitat-ground: $\mathrm{p}$-adj $=2.90 \mathrm{e}-09$ ). Stormwater roofs and ground sites were significantly different from each other (stormwater-ground: $\mathrm{p}$-adj= $1.30 \mathrm{e}-05)$. 


\section{Indicator Species}

On habitat roofs, none of the 4 most highly abundant species were selected as indicator species (Table 2). This is likely because three of these species were also common at SW roofs (Harpalus affinis, Xantholinus linearis, Gabrius appendiculatus), while the fourth species (Trechus obtusus) was found at 4 of 5 ground sites. Instead, species ranked 5 and 11 were found to have high specificity (i.e., found primarily at habitat roof sites) and sensitivity (i.e.,found at all habitat roof sites). The most strongly associated species with habitat roofs was a carabid Stenolophus conjunctus, (Indicator Value [IndVal] = 0.98, $\mathrm{p}=$ 0.008). A second indicator species for habitat roofs was the "ladybird" beetle Hippodamia convergens (Indicator Value [IndVal] $=0.93, p=0.066$ ).

On stormwater roofs, the most abundant species, carabid Elaphropus parvulus, was the only indicator species (IndVal $=1, \mathrm{p}=0.012$ ). This small carabid represented $27.5 \%$ of total individuals sampled on SW roofs and was present only at SW roof sites.

On the ground, the first and second most abundant species were also indicator species. These species were large bodied staphylinid Philonthus cognatus (IndVal $=0.89, p=0.038$ ) and carabid Nebria brevicollis (IndVal $=0.99, p=0.009$ ). When combined, these species account for $42.9 \%$ of individuals sampled. Philonthus cognatus was not found on roofs in Portland, while Nebria brevicollis was found in small numbers (3 individuals) on study roofs. Both species have been found in greater abundance on a rural-suburban roof outside Portland (Gonsalves and Starry, unpublished data). Four other less abundant species were also strongly associated with the ground. One Nitidulidae species, Carpophilus lugubris (IndVal = 0.91, p = 0.060); two Curculionidae species Sphenophorus parvulus and Sitona cylindricollis (IndVal $=0.89, \mathrm{p}=0.046$ and IndVal $=0.78, \mathrm{p}=0.075)$; and one Staphylinidae species, Atheta fungi (IV = $0.86, \mathrm{p}=0.090)$.

\section{Community Similarity}

Overall, all sites were relatively dissimilar from each other, with an average BC dissimilarity index of 0.76 . The stormwater roofs clustered together in the hierarchical tree which minimized within-group variance (Fig 3), but the community at one of the stormwater roofs had strong dissimilarity ( 0.90 and 0.94 ) to the communities at the other two stormwater roofs, which were more similar to each other (0.66). Two of the habitat roofs clustered with one of the ground locations ((HAB2, HAB3, and GND2; Fig 3). These two habitat roofs in this cluster had the lowest dissimilarity of any pair of locations (0.40). Community dissimilarity between HAB2 and GND2 was 0.67 , while dissimilarity was slightly lower (0.58) between HAB3 and GND2. A third cluster was made up of one of habitat roofs and the other four ground locations (HAB1, GND1,3, 4, and 5). Community dissimilarity in this cluster ranged from 0.52 between GND1 and GND4 to 0.73 between GND5 and both HAB3 and GND1.

\section{Discussion}

We found that green spaces on the ground have a richer beetle community with a greater number of both beetle species and individuals than green roofs, a finding consistent with other studies of insects on green roofs (Maclvor and Lundholm 2011; Tonietto et al. 2011). However, when compared at equal sample coverage, habitat roofs had significantly greater Shannon diversity (Hill number $q=1$ ) compared to the ground and to stormwater roofs. Stormwater roofs had the least number of individuals and lowest richness $(q=0)$ but had similar Shannon and Simpson diversity $(q=2)$ to ground sites. The finding that habitat roofs have greater Shannon diversity (although ground sites had nearly two times as many species) indicates that purposeful "biodiverse" design elements may increase green roof and urban biodiversity by supporting more even communities. Our finding that habitat roofs had greater richness and Shannon diversity than the more simply designed stormwater roofs supports the habitat complexity hypothesis, since habitat roofs had more layers of vegetations, varied substrate depth, and elements such as logs and stones.

We estimated diversity in terms of sample coverage, rather number of individual samples because this ensures that each community is sufficiently sampled and that comparisons are made between samples of equal completeness (Chao and Jost 2012). The use of sample coverage takes into account that ground and roof sites may be fundamentally different from each other in terms of abundance and richness. Based on smaller size, younger age, and lower accessibility, it is unlikely green roofs would have more species or more individuals than green spaces on the ground. However, green roofs generally experience less disturbance from public use or maintenance such as trimming and mowing and may provide refuge habitat for some more mobile species. This is supported by the finding of 11 species that were only on green roofs, 9 of which were found only on habitat roofs.

Additionally, we examined multiple metrics for diversity (Hill numbers $q=0,1$, and 2 ) to account for the fact that while older, larger ground sites had more species than roofs, they were also dominated by a few common species: on the ground just 6 species made up $75 \%$ of total abundance. Both Shannon and Simpson diversity take into account relative abundance of species and may be more reflective of roles in ecosystem function. Greater Shannon diversity on habitat roofs, as compared to both stormwater roofs and the ground, corresponded to more even representation in functional feeding groups, though some groups were represented by only one or two species. As Hill numbers increase, estimated diversity is less influenced by rare species. This effect explains why Simpson diversity on the ground was similar to that on stormwater roofs. At both site types asmall number of dominant species made up over three-quarters of total abundance.

Consistent with other studies of invertebrates on green roofs compared to the ground, we found that the distribution of beetle body sizes was different between habitat roofs, stormwater roofs, and the ground (Ksiazek et al. 2012; Tonietto et al. 2011). Habitat roofs had the greatest number of medium-bodied species, while ground sites had the greatest number of large-bodied species and relatively few small-bodied species. Stormwater roofs had the most even distribution of species by body size but had the greatest number of small-bodied species and the fewest large-bodied species. The greater presence of medium bodied species on the habitat roofs may reflect a more balanced system not dominated by small wind-delivered species or larger macro-predators (Starry et al. 2018). This pattern may also perhaps be due to the increased moisture capacity of habitat roofs that will support larger insects that would 
otherwise need refuge at greater substrate depths to survive dryness, while a small body size offers more opportunities to escape from thinner and drier stormwater roofs.

Indicator species analysis showed that habitat roofs were characterized by the small native ground beetle Stenolophus conjunctus (Say), which often cooccurs and may compete with the non-native ground beetle Elaphropus parvulus (Dej.) that was characteristic of the stormwater roofs (LaBonte 1998). Habitat roofs were characterized by Hippodamia convergens (Guerin), an important pest predator. This native lady beetle, while not threatened, has been displaced in some areas by the introduced lady beetle Coccinella septempunctata L., which was also common at roof and ground sites (Alyokhin and Sewell 2004; Bahlai et al. 2014). Therefore, habitat roofs may also do a better job than stormwater roofs at provisioning desirable native insect species in the urban area. Ground sites, on the other hand, were characterized by the large-bodied generalist rove beetle, Philonthus cognatus and the invasive ground beetle, Nebria brevicollis, which is now found extensively throughout Oregon (LaBonte 2011). Though the neozoon Nebria brevicollis was strongly associated with ground sites, it was found on both habitat and stormwater roofs, confirming previous documentation of its ability to fly in the Pacific Northwest of North America (LaBonte 2011). To our knowledge, this species is not documented to fly in its native European range.

Clustering of beetle communities based on similarity resulted in three distinct clusters, one of which included only stormwater roofs. This result supports previous findings that urban arthropod community similarity is more related to local site characteristics such as land-use and vegetation, than to physical distance (Braaker et al. 2014; Kyrö et al. 2017). However, though stormwater roofs clustered together, indicating their uniqueness from habitat roofs and the ground, they were also relatively dissimilar to each other. One of the stormwater roofs in particular was unique compared to other two stormwater roofs. This may have been related to its larger size or greater amount of shading it received from other buildings, or it may indicate a more stochastic component to what species are found on the more simply designed stormwater roofs. In a spider study of 16 sites on the ground in urban ruderal locations and vegetated railroad areas with 6 green roofs in Basel (Switzerland), clear clustering was evident between the green roofs that were not structurally rich. One green roof site included in this study that was rich in structure clustered together with comparable vegetated sites on the ground in a similarity comparison (Brenneisen 2006b).

These findings in Portland may be applicable in other locations: a global comparison of beetle species from 41 green roofs in 5 different cities indicated that, among other factors such as city, roof type was a significant predictor of community composition (Starry et al. 2018). A study of over 100 green roofs in France found a positive correlation between roofs types with more layers of vegetation and arthropod diversity. In Zurich, roof characteristics like the amount of herbaceous vegetation were more important than surrounding land cover or habitat connectivity metrics for determining community composition of lower mobility arthropods such as carabids and spiders (Madre et al.2013; Braaker et al. 2014).

The majority of studies in a wide range of habitats have documented a positive correlation between various measures of habitat complexity and species richness, though this relationship is not universal (see reviews by Tews et al. 2004 and Kovalenko et al. 2012). Some authors have speculated that the lack of relationship between habitat complexity and species richness found in some studies could be due to a mismatch in attributes of complexity like size or spacing (Palmer et al.; 2009; St. Pierre and Kovalenko, 2014). Habitat complexity is thought to influence species richness independent of habitat area (Kovalenko et al. 2012; Kolusa et al. 2012). Our research and other studies of green roofs suggests that appropriately chosen vegetation and other efforts to increase green roof habitat complexity are effective in enhancing beetle and other arthropod community diversity. More work is needed to understand which specific components of habitat complexity on green roofs result in the greatest increases diversity for target taxa. Additionally, some elements that increase complexity such as areas of deeper substrate can also add substantial weight and therefore cost to a green roof design. Having a better understanding of what specific features and spatial scale of habitat complexity are most beneficial on green roofs would allow designers to incorporate those features. Future studies of green roofs could include quantitative metrics of habitat complexity such as have been used in studies of other types of habitats to shed light in this area.

Urbanization poses one of the greatest threats to global biodiversity, yet urban green spaces are now acknowledged as critical to conserving native biodiversity, including insect and other invertebrate biodiversity. Though most insect species are not well known or charismatic, they are critical to the basic functioning of ecosystems (Wilson 1987) and provide important ecosystem services in urban areas, including pollination, pest management, and decomposition (Gómez-Baggethun et al. 2013). Urban green spaces also perform the innate service of providing refuge and habitat for species affected by land-use change (Gómez-Baggethun et al. 2013; Aronson et al. 2017). Our study provides further evidence that, despite generally being small and more isolated, green roofs are an important part of the urban green infrastructure. However, as with other urban green spaces, design is a critical component for determining the overall value of green roofs for biodiversity conservation.

\section{Author Declarations}

Funding: This research was partially supported by Sigma Xi Grants in Aid of Research and an Edward D. and Olive C. Bushby Scholarship

Conflicts of interest/Competing interests: The authors have none to disclose

Ethics approval: None was required for this research

Consent to participate: None was required for this research 
Consent for publication: All authors gave consent to submit for publication

Availability of data and material: data from this work is provided in a supplemental file

Code availability: R Statistical Software and libraries, open source

Authors contribution: All authors contributed to the study conception and design. Sampling methods were developed by Stephan Brenneisen. Material preparation and data collection were performed by Sydney Gonsalves and Olyssa Starry. Data analysis was performed by Sydney Gonsalves. Taxonomic identification was performed by Alex Szallies. The first draft of the manuscript was written by Sydney Gonsalves and reviewed by Olyssa Starry. All authors commented on previous versions of the manuscript. All authors read and approved the final manuscript.

Acknowledgements: This research was partially supported by a Sigma Xi Grant in Aid of Research and an Edward D. and Olive C. Bushby Scholarship. The authors would like to thank Dr. Andrew Moldenke (Oregon State University, retired) for his assistance in assigning beetle feeding groups; Drs. Catherine de Rivera and Amy Larson (Portland State University) for their graduate advisorship of Ms. Gonsalves, advice, and critical readings of early versions of this manuscript; and Dr. Susan Masta (Portland State University) for her advice and adoption of the green roof spiders we collected. We thank the following individuals for contributing to lab and field work: Daniel Dayrit, Aramee Diethelm, Maggie Gardner, Whitney McClees, Danielle Miles, Konrad Miziolek, Matt Przyborski, Vanessa Robertson-Rojas, Jacob Stone, Jessica Szabo, Amy Truitt. Additionally, Ms. Gonsalves would like to thank all members of the de RiveraLarson lab for their helpful discussions and peer review during the course of this work.

\section{References}

Alyokhin A, Sewell G (2004) Changes in a lady beetle community following the establishment of three alien species. Biological Invasions 6: $463-471$.

Angold PG, Sadler JP, Hill MO, Pullin A, Rushton S, Austin K, Small E, Wood B, Wadsworth R, Sanderson R, Thompson K (2006) Biodiversity in urban habitat patches. Sci Total Environ 360:196-204. https://doi.org/10.1016/j.scitotenv.2005.08.035

Aronson MF, Lepczyk CA, Evans KL, Goddard MA, Lerman SB, Maclvor JS, Nilon CH, Vargo T (2017) Biodiversity in the city: key challenges for urban green space management. Frontiers in Ecology and the Environment 15(4):189-96. https://doi.org/10.1002/fee.1480

Bates AJ, Mackay R, Greswell RB, Sadler JP (2009) SWITCH in Birmingham, UK: experimental investigation of the ecological and hydrological performance of extensive green roofs. Rev Environ Sci Biotechnol 8:295-300. https://doi.org/10.1007/s11157-009-9177-8

Bates AJ, Sadler JP, Mackay R (2013) Vegetation development over four years on two green roofs in the UK. Urban For Urban GREE 12(1):98-108. https://doi.org/10.1016/j.ufug.2012.12.003

Benjamini, Y,Hochberg Y (1995) Controlling the false discovery rate: a practical and powerful approach to multiple testing. Journal of the Royal Statistical Society Series B, 57: 289-300. http://www.jstor.org/stable/2346101

Borcard D, Gillet F, Legendre P (2018) Numerical Ecology in R. Springer. New York, New York.

Braakar S, Ghazoul J, Obrist MK, Moretti M (2014) Habitat connectivity shapes urban arthropod communities: the key role of green roofs. Ecology 95(4):1010-1021.

Brenneisen S (2003) Ökologisches Ausgleichspotenzial von extensiven Dachbegrünungen-Bedeutung für denArten- und Naturschutz und die Stadtentwicklungsplanung. Doctoral dissertation, Institute of Geography, University of Basel.

Brenneisen S (2006a) Space for urban wildlife: Designing green roofs as habitats in Switzerland. Urban Habitats 4:27-36.

Brenneisen, S \& Hänggi, A. (2006b): Begrünte Dächer - ökofaunistische Charakterisierung eines Habitatstyps in Siedlungsgebieten anhand eines Vergleichs der Spinnenfauna von Dach-begrünungen mit naturschutzrelevanten Bahnarealen in Basel (Schweiz). In: Mitteilungen der Naturforschenden Gesellschaften beider Basel 9 (2006), 99-122

Bright DE, Bouchard P (2008) Weevils of Canada and Alaska: Coleoptera, curculionidae, entiminae. NRC Research Press

Burkepile DE, Thurber RV (2019) The long arm of species loss: How will defaunation disrupt ecosystems down to the microbial scale? BioScience 69:443454. https://doi.org/10.1093/biosci/biz047 
Cameron KH, Leather SR (2012) How good are carabid beetles (Coleoptera, Carabidae) as indicators of invertebrate abundance and order richness? Biodivers Conserv 21:763-779. https://doi.org/10.1007/s10531-011-0215-9

Chao A., Jost, L (2012) Coverage-based rarefaction and extrapolation: standardizing samples by completeness rather than size. Ecology 93 (12),2533-2547. https://doi.org/10.1890/11-1952.1

Chao A, Gotelli NJ, Hsieh TC, Sandler E.L, Ma KH, Colwell RK, \& Ellison AM (2014). Rarefaction and extrapolation with Hill numbers: a framework for sampling and estimation in species diversity studies. Ecological Monographs 84(1) 45-67.

Colwell,RK, Chao A, Gotelli, N.J, Lin S Y, Mao CX, Chazdon RL Longino J T (2012). Models and estimators linking individual-based and sample-based rarefaction, extrapolation, and comparison of assemblages. Journal of Plant Ecology 5(1) 3-21

Cook-Patton SC, Bauerle TL (2012) Potential benefits of plant diversity on vegetated roofs: A literature review. J Environ Manage 106:85-92. https://doi.org/10.1016/j.jenvman

.2012 .04 .003

Croci S, Butet A, Georges A, Aguejdad R, Clergeau P (2008) Small urban woodlands as biodiversity conservation hot-spot: A multi-taxon approach. Landscape Ecol 23:1171-1186. https://doi.org/10.1007/s10980-008-9257-0

De Cáceres, M (2020) How to use the indicspecies R package (ver. 1.7.8). February 4, 2020. Accessed at https://cran.rproject.org/web/packages/indicspecies/vignettes/indicspeciesTutorial.pdf July 2020.

Cáceres MD, Legendre P (2009) Associations between species and groups of sites: indices and statistical inference. Ecology 90(12):3566-74.

Duelli P, Obrist MK (1998) In search of the best correlates for local organismal biodiversity in cultivated areas. Biodivers Conserv 7:297-309. https://doi.org/10.1023/A:1008873510817

Ellison A M (2010) Partitioning Diversity. Ecology 91(7):1962-1963. https://doi.org/10.1890/09-1692.1

Fattorini S, Sciotti, A, Patrizio, T, Di Guillio, A. (2013). Species distribution, ecology, abundance, body size, and phylogeny, originate interrelated rarity patterns at regional scale. Journal of Zoological Systematics and Evolutionary Research. 51(4): 279-286. https://doi.org/10.1111/jzs.12026

Gedge D, Kadas G (2005) Green roofs and biodiversity. Biologist 52:161-169

Kadas, G. (2006) Rare invertebrates colonizing green roofs in London. Urban Habitats 4:66-86.

Goddard MA, Dougill AJ, Benton TG (2010) Scaling up from gardens: biodiversity conservation in urban environments. Trends Ecol Evol 25:90-98. https://doi.org/10.1016/j.tree.2009.07.016

Gómez-Baggethun E, Gren Å, Barton DN, Langemeyer J, McPhearson T, O'Farrell P, Andersson E, Hamstead Z, Kremer P (2013) Urban ecosystem services. In Urbanization, biodiversity and ecosystem services: Challenges and opportunities (pp. 175-251). Springer, Dordrecht.

City of Toronto (2020). Accessed September 9, 2020. Retrieved from https://www.toronto.ca/city-government/planning-development/official-planguidelines/green-roofs/

Grimm NB, Pickett STA, Hale RL, Cadenasso ML (2017) Does the ecological concept of disturbance have utility in urban social-ecological-technological systems? Ecosystem Health and Sustainability 3:e01255. https://doi.org/10.1002/ehs2.1255

Hill MO (1973) Diversity and Evenness: A unifying notion and its consequences. Ecology 54(2) 427-432. https://doi.org/10.2307/1934352

Hsieh TC, Ma KH, \& Chao A (2020) iNEXT: iNterpolation and EXTrapolation for species diversity. R package version 2.0.20 Retrieved from :http://chao.stat.nthu.edu.tw/wordpress/software-download/.

Ido S, Shimrit P-F (2015) Blue is the new green - Ecological enhancement of concrete based coastal and marine infrastructure. Ecol Eng 84:260-272. https://doi.org/10.1016/j.ecoleng.2015.09.016

Jones EL, Leather SR (2012) Invertebrates in urban areas: A review. Eur J Entomol 109:463-478. https://doi.org/10.14411/eje.2012.060

Jost L, DeVries P, Walla, T, Greeney H, Chao A. Ricotta C (2010). Partitioning diversity for conservation analyses. Diversity and Distributions 16 (1):65-76.

Kadas G (2006) Rare invertebrates colonizing green roofs in London. Urban Habitats 4(1):66-86.

Kindler SD, Spomer SM (1986) Observations on the Biology of the Bluegrass Billbug, Sphenophorus parvulus Gyllenhal (Coleoptera: Curculionidae), in an Eastern Nebraska Sod Field. Journal of the Kansas Entomological Society 59:26-31

Kovalenko KE, Thomaz SM, Warfe DM (2012) Habitat complexity: approaches and future directions. Hydrobiologia 685:1-17.

https://doi.org/10.1007/s10750-011-0974-z

Page 9/16 
Kowarik I (2011) Novel ecosystems, biodiversity, and conservation. Environmental Pollution 159(8-9):1974-1983.

Ksiazek K, Fant J, Skogen K (2012) An assessment of pollen limitation on Chicago green roofs. Landscape Urban Planning 107:401-408.

Kyrö, K., Brenneisen, S., Kotze, D.J., Szallies, A., Gerner, M., Lehvävirta, S. (2017): Local habitat characteristics have a stronger effect than the surrounding urban landscape on beetle communities on green roofs. Urban Forestry \& Urban Greening 29 (2018) 122-130

Landolt, E. (2001) Orchideen-Wiesen in Wollishofen (Zürich) - ein erstaunliches Relikt aus dem Anfang des 20. Jahrhunderts. In: Vierteljahreschrift der Naturforschenden Gesellschaft in Zürich 146/2-3: 41-51

LaBonte J R, Nelson R E (1998). North American distribution and habitat of Elaphropus parvulus (Dejean), an introduced, non-Synanthropic Carabid Beetle (Coleoptera: Carabidae). The Coleopterists Bulletin, 52(1): 35-42.

LaBonte JR (2011) Nebria brevicollis (Fabricius, 1792) in North America, benign or malign? (Coleoptera, Carabidae, Nebriini). ZooKeys, 147: $497-543$.

Liebherr JK, Takumi RL (2002) Introduction and Distributional Expansion of Trechus obtusus (Coleoptera: Carabidae) in Maui, Hawai'i. Pacific Science 56:365-375. https://doi.org/10.1353/psc.2002.0035

Lorimer J (2008) Living roofs and brownfield wildlife: Towards a fluid biogeography of UK nature conservation. Environ Plan A 40:2042-2060.

https://doi.org/10.1068/a39261

MacArthur RH, MacArthur JW (1961) On bird species diversity. Ecology 42:594-598. https://doi.org/10.2307/1932254

MacArthur, RH, Wilson, EO (1967). The theory of island biogeography. Princeton, New Jersey: Princeton University Press.

Maclvor JS, Lundholm J (2011) Insect species composition and diversity on intensive green roofs and adjacent level-ground habitats. Urban Ecosyst 14:225-241. https://doi.org/10.1007/s11252-010-0149-0

Maclvor JS (2015) Building height matters: Nesting activity of bees and wasps on vegetated roofs. Isr J Ecol Evol 62:88-96.

https://doi.org/10.1080/15659801.2015.1052635

Madre F, Vergnes A, Machon N, Clergeau P (2013) A comparison of 3 types of green roof as habitats for arthropods. Ecol Eng 57:109-117.

https://doi.org/10.1016/j.ecoleng.2013.04.029

Majka CG, Bousquet Y, Westby S (2007) The ground beetles (Coleoptera: Carabidae) of the Maritime Provinces of Canada: review of collecting, new records, and observations on composition, zoogeography, and historical origins. Zootaxa 1-36

McAbendroth, L, Ramsay PM, Foggo, A,Rundle SD, Bilton DT (2005). Does macrophytes fractal complexity drive invertebrate diversity, biomass and body size distributions? Oikos 111: 279-290.

McIntyre NE, Rango J, Fagan WF, Faeth SH (2001) Ground arthropod community structure in a heterogeneous urban environment. Landscape Urban Plan 52:257-274. https://doi.org/10.1016/S0169-2046(00)00122-5

McKinney ML (2006) Urbanization as a major cause of biotic homogenization. Biological Conservation 127:247-260.

https://doi.org/10.1016/j.biocon.2005.09.005

Moldenke, A R (1999) Soil-dwelling arthropods: their diversity and functional roles. In RT Meurisse, WG. Ypsilantis, \& C Seybold (Eds.), Proceedings: Pacific Northwest Forest and Rangeland Soil Organism Symposium. U.S. Department of Agriculture Forest Service General Technical Report PNW-GTR-4619 (pp. 3344).

Niemela, J, Kotze, DJ (2009) Carabid beetle along urban to rural gradients: A review. Landscape Urban Planning 92(2), 65-71.

https://doi.org/10.1016/j.landurbplan.2009.05.016

Nikles, E., Knobel, B., Reisner, Y. (2020) Flachdachbegrünung. Flachdächer richtig begrünen - das ökologische Potenzial nutzen. Editor: Bau- und Verkehrsdepartement des Kantons Basel-Stadt, Stadtgärtnerei Basel.

Oksansen J, Guillaume Blanchet F, Friendly M, Kindt,R, Legendre P, McGlinn D, ... Wagner H (2019) R Package, 'vegan'. Accessed at https://cran.ism.ac.jp/web/packages/vegan/vegan.pdf

Palmer MA, Menninger HL, Bernhardt E (2010) River restoration, habitat heterogeneity and biodiversity: a failure of theory or practice? Freshwater Biol 55:205-222. https://doi.org/10.1111/j.1365-2427.2009.02372.x

Pataki DE (2015) Grand challenges in urban ecology. Front Ecol Evol 3, 57. https://doi.org/10.3389/fevo.2015.00057

Pétremand, G, Chittaro, Y, Braaker, S, Brenneisen, S, Gerner, M, Obrist, MK, Rochefort, S, Szallies, A, Moretti, M. (2017) Ground beetle (Coleoptera: Carabidae) communities on green roofs in Switzerland: synthesis and perspectives. Urban Ecosystems 21:119-132. 
Pétremand, G., Bénon, D, Rochefort, S (2018) Abondance et diversité de l'apifaune (Hymenoptera, Anthophila)des toitures végétalisées de l'agglomération genevoise. ENTOMO HELVETICA 11: 105-116

Pickett STA, Cadenasso ML, Grove JM, Boone CG, Groffman PM, Irwin E, Kaushal SS, Marshall V, McGrath BP, Nilon CH, Pouyat RV, Szlavecz K, Troy A, Warren P (2011) Urban ecological systems: Scientific foundations and a decade of progress. J Environ Manage 92:331-362. https://doi.org/10.1016/j.jenvman.2010.08.022

Pickett STA, Cadenasso ML, Grove JM, Groffman PM, Band LE, Boone CG, Burch WR, Grimmond CSB, Hom J, Jenkins JC, Law NL, Nilon CH, Pouyat RV, Szlavecz K, Warren PS, Wilson MA (2008) Beyond urban legends: An emerging framework of urban ecology, as illustrated by the Baltimore ecosystem study. BioScience 58:139-150. https://doi.org/10.1641/B580208

Rosenzweig, ML(2003) Reconciliation ecology and the future of species diversity. Oryx 37:194-205.

Srivastava, DS (2006). Habitat structure, trophic structure and ecosystem function: interactive effects in a bromeliad-insect community.0ecologia,149 493504 .

Starry O, Gonsalves S, Ksiazek-Mikenas K, Maclvor JS,Gardner M ,Szallies A, Brenneisen S (2018) A Global Comparison of Community Composition on Green Roofs and the Potential for Homogenization. Urban Naturalist 1:1-15.

Starry, O (2020) Portland Ecoroof Map. https://homeecologyresearch.com/ecoroof-map. Accessed November 29, 2020.

St. Pierre, Jl, Kovalenko K (2014) Effect of habitat complexity attributes on species richness. Ecosphere 5(2):1-10. http://dx.doi.org/10.1890/ES13-00323.1

Sunderland K, Lovei G, Fenlon J (1995) Diets and Reproductive Phenologies of the Introduced Ground Beetles Harpalus-Affinis and Clivina-Australasiae (Coleoptera, Carabidae) in New-Zealand. Aust J Zool 43:39-50

Tews J, Brose U, Grimm V, Tielbörger K, Wichmann MC, Schwager M, Jeltsch F (2004) Animal species diversity driven by habitat heterogeneity/diversity: The importance of keystone structures. J Biogeogr 31(1):79-92. https://doi.org/10.1046/j.0305-0270.2003.00994.x

Tonietto R, Fant J, Ascher J, Ellis K, Larkin D (2011) A comparison of bee communities of Chicago green roofs, parks and prairies. Landscape Urban Plan 103:102-108. https://doi.org/10.1016/j.landurbplan.2011.07.004

Tscharntke, T, Steffan-Dewenter, I. Kruess, A, Theis, C (2002) Characteristics of insect populations on habitat fragments: A mini review. Ecological Research 17: 229-239.

Ward DF, New TR, Yen AL (2001) Effects of pitfall trap spacing on the abundance, richness and composition of invertebrate catches. J Insect Conserv 5:4753. https://doi.org/10.1023/A:1011317423622

Williams NSG, Lundholm J, S Maclvor J (2014) FORUM: Do green roofs help urban biodiversity conservation? J Appl Ecol 51:1643-1649.

https://doi.org/10.1111/1365-2664.12333

Woodcock BA (2005) Pitfall trapping in ecological studies. In: Insect sampling in forest ecosystems S.R. Leather, J.H. Lawton and G.E. Likens (Eds.) Malden, Massachusetts: Blackwell Scientific, Ltd.

\section{Tables}

Table 1 Details of study green roofs and ground-level green spaces. Green space ages are exact for green roofs and approximated based on historical aerial images for ground sites. 


\begin{tabular}{|c|c|c|c|c|c|c|c|c|c|c|}
\hline $\begin{array}{l}\text { Site } \\
\text { Type } \\
\text { and } \\
\text { Code }\end{array}$ & Neighborhood & Maintenance & Age & $\begin{array}{l}\text { Average } \\
\text { Substrate } \\
\text { Depth } \\
(\mathrm{mm})\end{array}$ & $\begin{array}{l}\text { Approximate } \\
\text { Building } \\
\text { Height (m) }\end{array}$ & $\begin{array}{l}\text { Approximate } \\
\text { Area (sq.m) }\end{array}$ & $\begin{array}{l}\text { Average } \\
\text { Vegetation } \\
\text { Height }^{\mathrm{a}} \\
\text { (cm) }\end{array}$ & $\begin{array}{l}\text { Average } \\
\text { Vegetation } \\
\text { Cover }\end{array}$ & $\begin{array}{l}\text { Vegetation } \\
\text { Layers }\end{array}$ & Description \\
\hline $\begin{array}{l}\text { Habitat } \\
\text { Roof } \\
\text { (HAB1) }\end{array}$ & $\begin{array}{l}\text { Central } \\
\text { Eastside } \\
\text { Commercial }\end{array}$ & $\begin{array}{l}\text { Irrigation } \\
\text { system not } \\
\text { in use, } \\
\text { limited } \\
\text { maintenance }\end{array}$ & 7 & 12 & 5.7 & 1858 & 14.2 & $73 \%$ & 3 & $\begin{array}{l}\text { Native } \\
\text { vegetation, } \\
\text { soil depth } \\
\text { variation }\end{array}$ \\
\hline $\begin{array}{l}\text { Habitat } \\
\text { Roof } \\
\text { (HAB2) }\end{array}$ & $\begin{array}{l}\text { Northwest } \\
\text { Industrial }\end{array}$ & $\begin{array}{l}\text { Hand } \\
\text { watering and } \\
\text { maintenance } \\
\text { as needed }\end{array}$ & 4 & 10 & 5.3 & 194 & 15.2 & $64 \%$ & 3 & $\begin{array}{l}\text { Native } \\
\text { vegetation, } \\
\text { woody } \\
\text { material, } \\
\text { soil depth } \\
\text { variation }\end{array}$ \\
\hline $\begin{array}{l}\text { Habitat } \\
\text { Roof } \\
\text { (HAB3) }\end{array}$ & Downtown & $\begin{array}{l}\text { Irrigation, } \\
\text { maintenance } \\
\text { as needed }\end{array}$ & 16 & 8 & 28.7 & 543 & 13.0 & $84 \%$ & 4 & $\begin{array}{l}\text { Native } \\
\text { herbaceous } \\
\text { vegetation, } \\
\text { woody } \\
\text { material, } \\
\text { soil depth } \\
\text { variation }\end{array}$ \\
\hline $\begin{array}{l}\text { SW } \\
\text { Roof } \\
\text { (SW1) }\end{array}$ & Pearl District & $\begin{array}{l}\text { Routine } \\
\text { irrigation } \\
\text { and } \\
\text { maintenance }\end{array}$ & 5 & 8 & 12.4 & 604 & 1.8 & $36 \%$ & 1 & $\begin{array}{l}\text { Low } \\
\text { drought } \\
\text { tolerant } \\
\text { plants, } \\
\text { solar } \\
\text { panels }\end{array}$ \\
\hline $\begin{array}{l}\text { SW } \\
\text { Roof } \\
\text { (SW2) }\end{array}$ & $\begin{array}{l}\text { Old } \\
\text { Town/China } \\
\text { Town }\end{array}$ & $\begin{array}{l}\text { Hand } \\
\text { watering and } \\
\text { maintenance } \\
\text { as needed }\end{array}$ & 3 & 9 & 15.5 & 227 & 3.4 & $67 \%$ & 1 & $\begin{array}{l}\text { Primarily } \\
\text { low } \\
\text { drought } \\
\text { tolerant } \\
\text { plants }\end{array}$ \\
\hline $\begin{array}{l}\text { SW } \\
\text { Roof } \\
\text { (SW3) }\end{array}$ & $\begin{array}{l}\text { Old } \\
\text { Town/China } \\
\text { Town }\end{array}$ & $\begin{array}{l}\text { Irrigation, } \\
\text { maintenance } \\
\text { as needed }\end{array}$ & 3 & 6 & 14.1 & 873 & 2.0 & $43 \%$ & 2 & $\begin{array}{l}\text { Primarily } \\
\text { low } \\
\text { drought } \\
\text { tolerant } \\
\text { plants, } \\
\text { solar } \\
\text { panels }\end{array}$ \\
\hline $\begin{array}{l}\text { Ground } \\
\text { (GND1) }\end{array}$ & $\begin{array}{l}\text { Central } \\
\text { Eastside } \\
\text { Commercial }\end{array}$ & Mowing & 10 & - & - & 2361 & - & $100 \%$ & 1 & Grassy lot \\
\hline $\begin{array}{l}\text { Ground } \\
\text { (GND2) }\end{array}$ & $\begin{array}{l}\text { Old } \\
\text { Town/China } \\
\text { Town }\end{array}$ & Mowing & 30 & - & - & 2340 & - & $100 \%$ & 1 & Grassy lot \\
\hline $\begin{array}{l}\text { Ground } \\
\text { (GND3) }\end{array}$ & Pearl District & $\begin{array}{l}\text { Mowing, } \\
\text { landscaping }\end{array}$ & 18 & - & - & 1025 & - & $95 \%$ & 4 & City park \\
\hline $\begin{array}{l}\text { Ground }{ }^{c} \\
\text { (GND4) }\end{array}$ & $\begin{array}{l}\text { Northwest } \\
\text { Industrial }\end{array}$ & None & - & - & - & 292 & - & $46 \%$ & 2 & $\begin{array}{l}\text { Low use } \\
\text { area of } \\
\text { railyard }\end{array}$ \\
\hline $\begin{array}{l}\text { Ground } \\
\text { (GND5) }\end{array}$ & Downtown & Landscaping & 50 & - & - & 650 & - & $72 \%$ & 4 & $\begin{array}{l}\text { University } \\
\text { green } \\
\text { space }\end{array}$ \\
\hline
\end{tabular}

1. Because of frequent mowing and landscaping vegetation height surveys were not performed at ground sites.

2. Substrate depth could not be determined at ground sites.

3. The age of the site was unclear from historical imagery.

Table 2 Indicator and five most common beetle species for habitat roofs, stormwater roofs, and ground-level green spaces. Feeding group assignment, native species status, body size group, and any additional notable descriptive information is provided. 


\begin{tabular}{|c|c|c|c|c|c|c|c|c|c|c|}
\hline Family & $\begin{array}{l}\text { Genus and } \\
\text { Species }\end{array}$ & Number & Rank & $\begin{array}{l}\text { Percent of } \\
\text { Total } \\
\text { Individuals }\end{array}$ & $\begin{array}{l}\text { Indicator } \\
\text { Species } \\
\text { Statistic } \\
\text { (IndVal) }\end{array}$ & $\begin{array}{l}\text { Indicator } \\
\text { Species } \\
\text { p-value }\end{array}$ & $\begin{array}{l}\text { Feeding } \\
\text { Group }\end{array}$ & $\begin{array}{l}\text { Native } \\
\text { Species } \\
\text { Status }\end{array}$ & $\begin{array}{l}\text { Body } \\
\text { Size } \\
\text { Group }\end{array}$ & $\begin{array}{l}\text { Additional } \\
\text { notable } \\
\text { description }\end{array}$ \\
\hline \multicolumn{11}{|c|}{ Habitat Roofs (403 total individuals) } \\
\hline Carabidae & $\begin{array}{l}\text { Harpalus } \\
\text { affinis (Schrk.) }\end{array}$ & 107 & 1 & 26.6 & - & - & $\begin{array}{l}\text { Facultative } \\
\text { herbivore, } \\
\text { omnivore }\end{array}$ & $\begin{array}{l}\text { Non- } \\
\text { native }\end{array}$ & Large & $\begin{array}{l}\text { Possibly play a } \\
\text { beneficial } \\
\text { biocontrol role in } \\
\text { agricultural } \\
\text { systems } \\
\text { (Sunderland et } \\
\text { al. 1995); } \\
\text { synanthropic } \\
\text { (Majka et al. } \\
\text { 2007). }\end{array}$ \\
\hline Staphylinidae & $\begin{array}{l}\text { Xantholinus } \\
\text { linearis (OI.) }\end{array}$ & 62 & 2 & 15.4 & - & - & Predator & $\begin{array}{l}\text { Non- } \\
\text { native }\end{array}$ & Medium & \\
\hline Staphylinidae & $\begin{array}{l}\text { Gabrius } \\
\text { appendiculatus } \\
\text { Sharp }\end{array}$ & 26 & 3 & 6.5 & - & - & $\begin{array}{l}\text { Predator, } \\
\text { detritivore }\end{array}$ & $\begin{array}{l}\text { Non- } \\
\text { native }\end{array}$ & Large & \\
\hline Carabidae & $\begin{array}{l}\text { Trechus } \\
\text { obtusus Er. }\end{array}$ & 16 & 4 & 4 & - & - & Predator & $\begin{array}{l}\text { Non- } \\
\text { native }\end{array}$ & Small & $\begin{array}{l}\text { Oregon } \\
\text { populations are } \\
\text { documented to } \\
\text { have a high } \\
\text { frequency of } \\
\text { macroptery } \\
\text { (Liebherr \& } \\
\text { Takumi 2002). }\end{array}$ \\
\hline Carabidae & $\begin{array}{l}\text { Stenolophus } \\
\text { conjunctus } \\
\text { (Say) }\end{array}$ & 15 & 5 & 3.7 & 0.98 & 0.008 & Predator & Native & Small & \\
\hline Coccinellidae & $\begin{array}{l}\text { Hippodamia } \\
\text { convergens } \\
\text { Guerin }\end{array}$ & 8 & 11 & 2 & 0.93 & 0.066 & Pest predator & Native & Small & \\
\hline \multicolumn{11}{|c|}{ Stormwater Roofs (69 total individuals) } \\
\hline Carabidae & $\begin{array}{l}\text { Elaphropus } \\
\text { parvulus (Dej.) }\end{array}$ & 19 & 1 & 27.5 & 1 & 0.012 & Predator & $\begin{array}{l}\text { Non- } \\
\text { native }\end{array}$ & Small & $\begin{array}{l}\text { Associated with } \\
\text { lacustrine and } \\
\text { riparian habitats } \\
\text { (LaBonte and } \\
\text { Nelson 1998). }\end{array}$ \\
\hline Staphylinidae & $\begin{array}{l}\text { Gabrius } \\
\text { appendiculatus } \\
\text { Sharp }\end{array}$ & 10 & 2 & 14.5 & - & - & $\begin{array}{l}\text { Predator, } \\
\text { detritivore }\end{array}$ & $\begin{array}{l}\text { Non- } \\
\text { native }\end{array}$ & Large & \\
\hline Staphylinidae & $\begin{array}{l}\text { Xantholinus } \\
\text { linearis (OI.) }\end{array}$ & 10 & 3 & 14.5 & - & - & Predator & $\begin{array}{l}\text { Non- } \\
\text { native }\end{array}$ & Medium & \\
\hline Staphylinidae & $\begin{array}{l}\text { Ocypus } \\
\text { aeneocephalus } \\
\text { (DeG.) }\end{array}$ & 8 & 4 & 11.6 & - & - & Megapredator & $\begin{array}{l}\text { Non- } \\
\text { native }\end{array}$ & Large & \\
\hline Carabidae & $\begin{array}{l}\text { Harpalus } \\
\text { affinis (Schrk.) }\end{array}$ & 6 & 5 & 8.7 & - & - & $\begin{array}{l}\text { Facultative } \\
\text { herbivore, } \\
\text { omnivore }\end{array}$ & $\begin{array}{l}\text { Non- } \\
\text { native }\end{array}$ & Large & $\begin{array}{l}\text { Possibly play a } \\
\text { beneficial } \\
\text { biocontrol role in } \\
\text { agricultural } \\
\text { systems } \\
\text { (Sunderland et } \\
\text { al. 1995); } \\
\text { synanthropic } \\
\text { (Majka et al. } \\
\text { 2007). }\end{array}$ \\
\hline \multicolumn{11}{|c|}{ Ground-level (3458 total individuals) } \\
\hline Staphylinidae & $\begin{array}{l}\text { Philonthus } \\
\text { cognatus } \\
\text { Steph. }\end{array}$ & 1074 & 1 & 31.1 & 0.89 & 0.038 & Megapredator & $\begin{array}{l}\text { Non- } \\
\text { Native }\end{array}$ & Large & \\
\hline Carabidae & $\begin{array}{l}\text { Nebria } \\
\text { brevicollis (F.) }\end{array}$ & 409 & 2 & 11.8 & 0.99 & 0.009 & Predator & Invasive & Large & $\begin{array}{l}\text { Rapidly } \\
\text { expanding range } \\
\text { and present in a } \\
\text { wide range of } \\
\text { habitats and } \\
\text { climates in } \\
\text { Oregon (LaBonte } \\
\text { 2011). }\end{array}$ \\
\hline Tenebrionidae & Blapstinus & 400 & 3 & 11.6 & - & - & Granivore, & Native & Medium & \\
\hline
\end{tabular}

Page 13/16 


\begin{tabular}{|c|c|c|c|c|c|c|c|c|c|c|}
\hline & $\begin{array}{l}\text { moestus } \\
\text { Melsh. }\end{array}$ & & & & & & detritivore & & & \\
\hline Carabidae & $\begin{array}{l}\text { Amara aenea } \\
(\text { DeG.) }\end{array}$ & 307 & 4 & 8.9 & - & - & Generalist & $\begin{array}{l}\text { Non- } \\
\text { Native }\end{array}$ & Medium & $\begin{array}{l}\text { Considered } \\
\text { synanthropic } \\
\text { (Majka et al. } \\
\text { 2007). }\end{array}$ \\
\hline Staphylinidae & $\begin{array}{l}\text { Philonthus } \\
\text { carbonarius } \\
\text { (Grav.) }\end{array}$ & 226 & 5 & 6.5 & - & - & Megapredator & $\begin{array}{l}\text { Non- } \\
\text { Native }\end{array}$ & Large & \\
\hline Nitidulidae & $\begin{array}{l}\text { Carpophilus } \\
\text { lugubris } \\
\text { Murray }\end{array}$ & 34 & 12 & 1 & 0.91 & 0.060 & Detritivore & Native & Small & \\
\hline Curculionidae & $\begin{array}{l}\text { Sphenophorus } \\
\text { parvulus Gyll. }\end{array}$ & 20 & 17 & 0.6 & 0.89 & 0.046 & Herbivore & $\begin{array}{l}\text { Non- } \\
\text { Native }\end{array}$ & Medium & $\begin{array}{l}\text { Turf grass pest } \\
\text { (Kindler and } \\
\text { Spomer 1986). }\end{array}$ \\
\hline Staphylinidae & $\begin{array}{l}\text { Atheta fungi } \\
\text { (Grav.) }\end{array}$ & 20 & 17 & 0.6 & 0.86 & 0.090 & $\begin{array}{l}\text { Generalist } \\
\text { pest predator }\end{array}$ & $\begin{array}{l}\text { Non- } \\
\text { Native }\end{array}$ & Small & \\
\hline Curculionidae & $\begin{array}{l}\text { Sitona } \\
\text { cylindricollis } \\
\text { (Fahrs.) }\end{array}$ & 5 & 28 & 0.1 & 0.78 & 0.075 & Herbivorous & $\begin{array}{l}\text { Non- } \\
\text { Native }\end{array}$ & Small & $\begin{array}{l}\text { Pest of sweet- } \\
\text { clover, alfalfa, } \\
\text { alsike clover, and } \\
\text { black medic } \\
\text { (Bright and } \\
\text { Bouchard 2008) }\end{array}$ \\
\hline
\end{tabular}

\section{Figures}

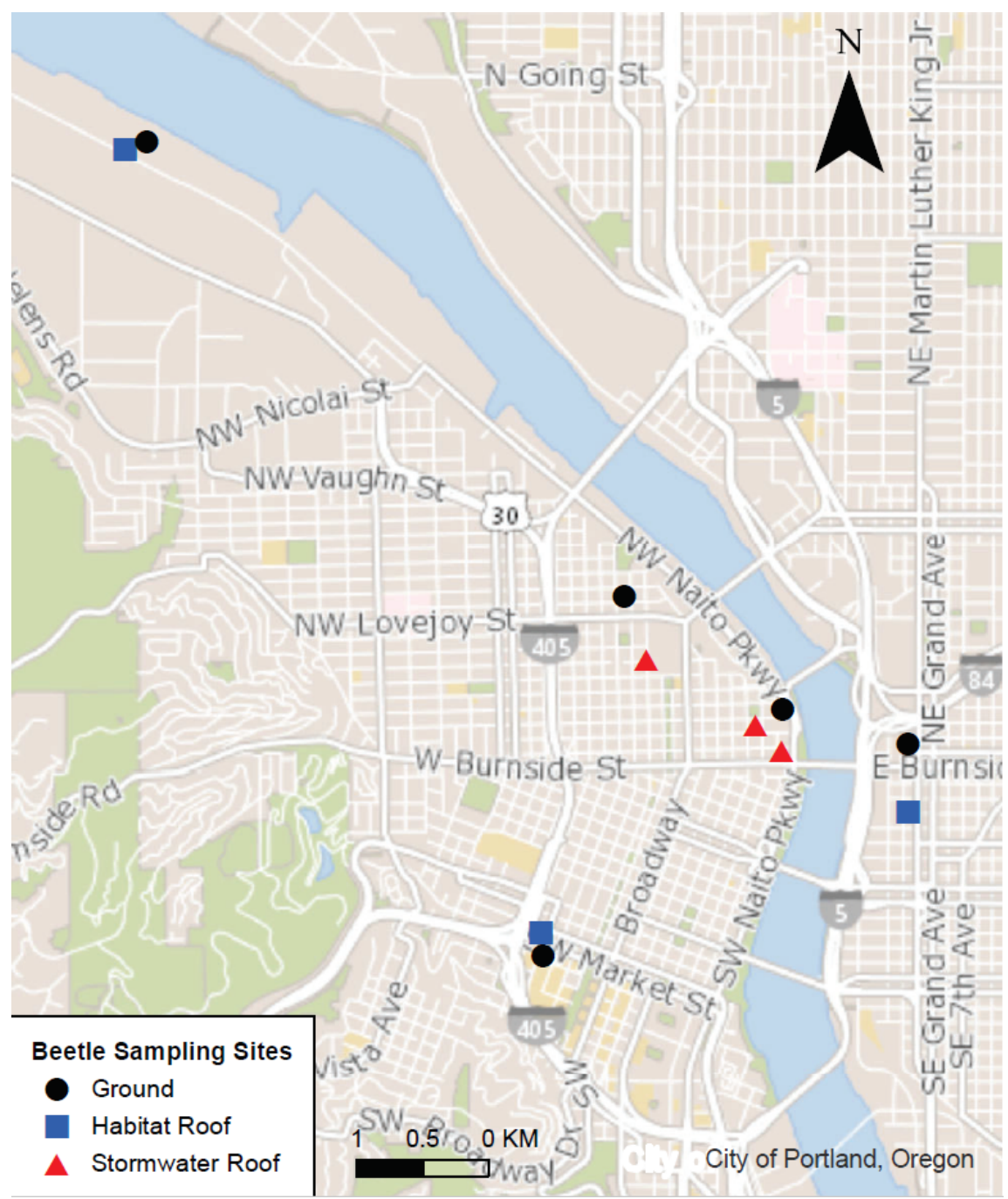

\section{Figure 1}

Map of Portland, Oregon, with locations of green roofs and ground-level green spaces. 

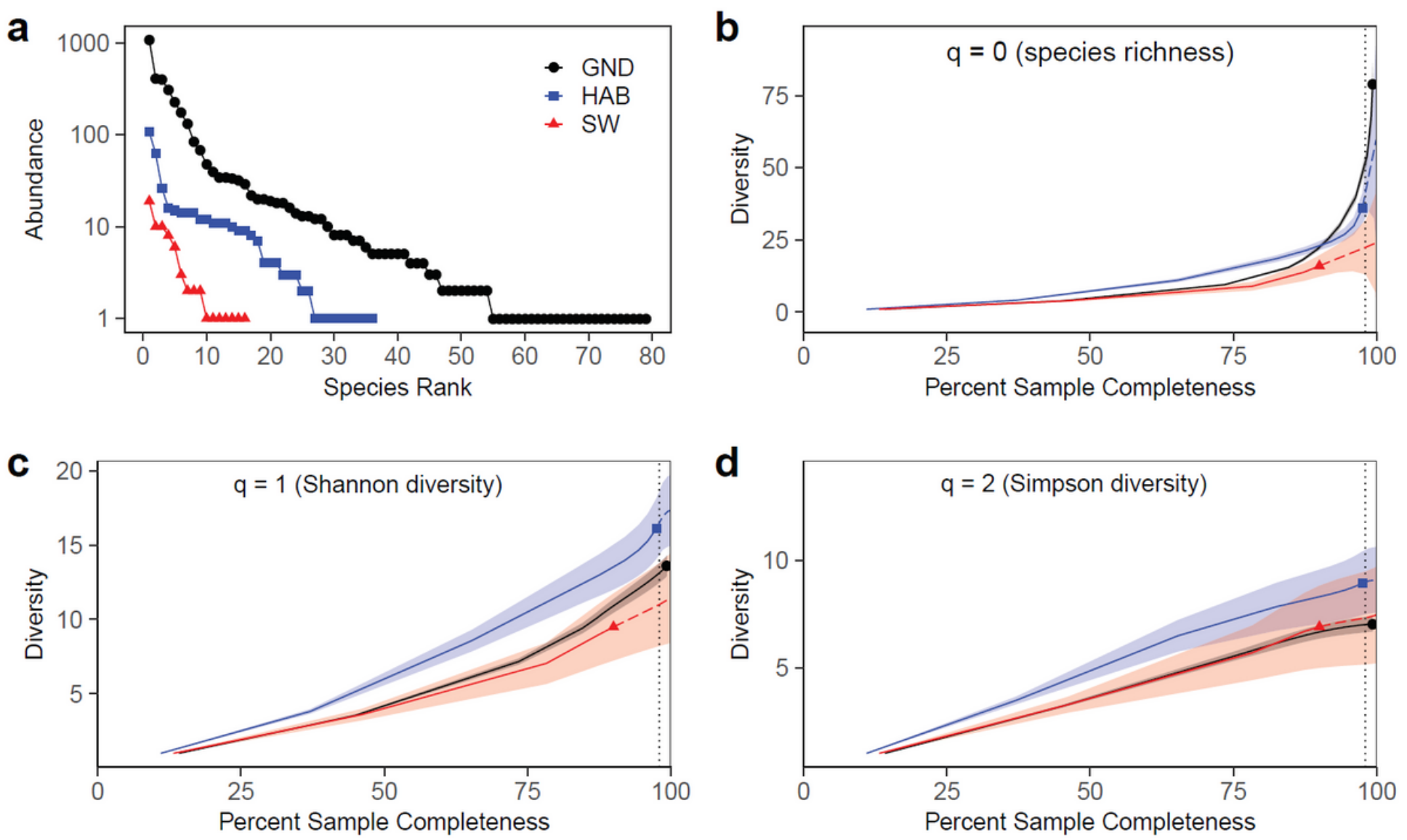

Figure 2

(a) Species rank abundance curves for ground-level green spaces (GND; circles), habitat roofs (HAB; squares), and stormwater roofs (SW; triangles). (b) Sample completeness-based rarefaction (solid line) and extrapolation (dashed line) curves for species richness (Hill number q = 0). (c) Sample completeness-based curves for Shannon diveristy (Hill number $q=1$ ). (d) Sample completeness-based curves for Simpson diveristy (Hill number $q=2$ ). Reference samples are shown as points using the same symbology as in panel (a). 


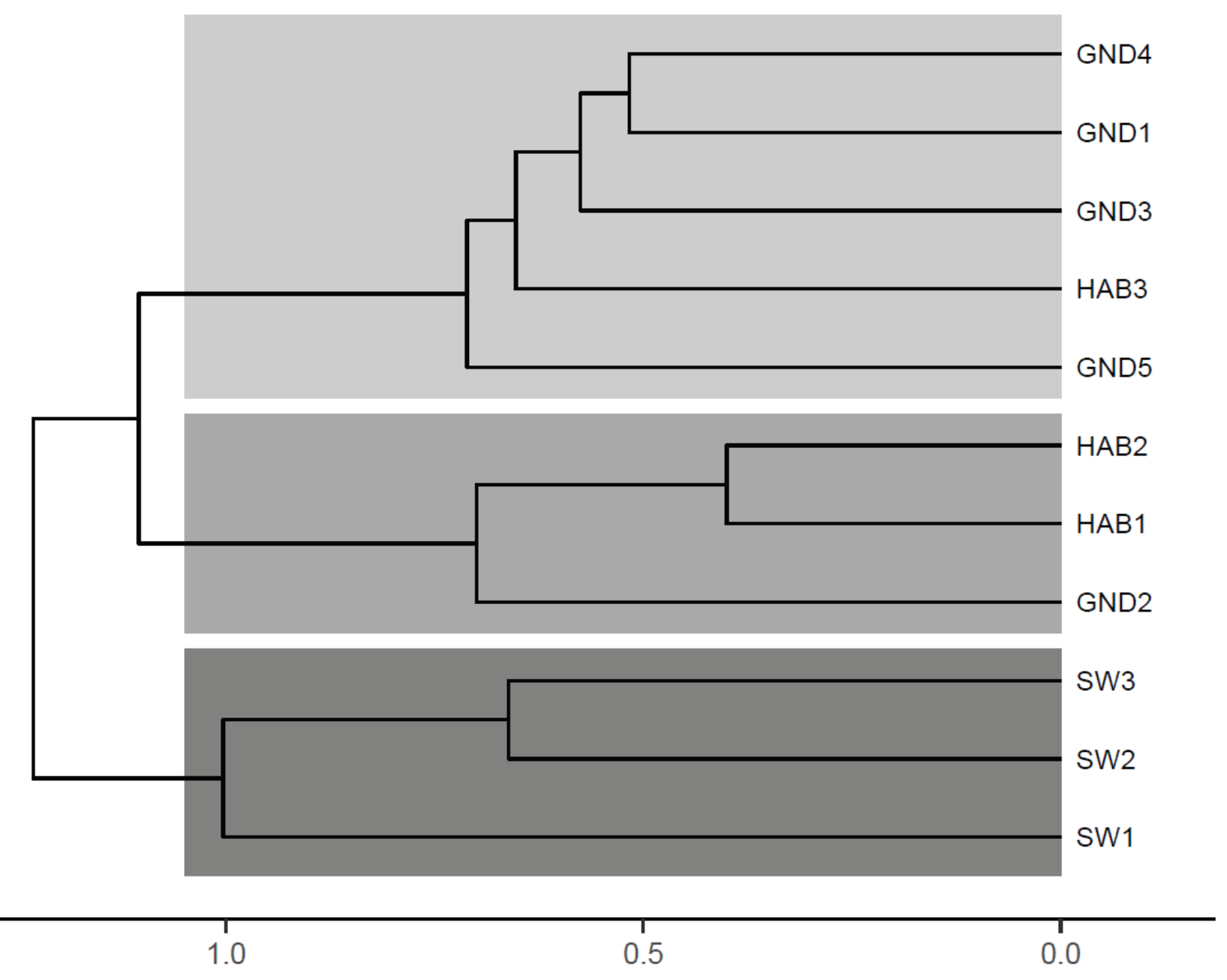

Figure 3

Ward's distance cluster tree on Bray-Curtis dissimilarity for sampled beetle communities. Shading indicates three major clustering groups. Notes: Fig 1 was created in ESRI ArcMap. Fig 2 and Fig 3 were created in R Statistical Software using the vegan, iNEXT, ggplot2, and ggdendro libraries. All figures were converted to .eps format using Adobe Editor.

\section{Supplementary Files}

This is a list of supplementary files associated with this preprint. Click to download.

- SupplementaryInformationGonsalvesetalSpeciesList.xlsx

- SupplementaryInformationGonsalvesetalSpeciesListRefs.docx 